\section{(6) OPEN ACCESS}

\title{
Reassessing the importance of 'lost pleasure' associated with smoking cessation: implications for social welfare and policy
}

\author{
Terry Frank Pechacek, ${ }^{1,2}$ Pratibha Nayak, ${ }^{3}$ Paul Slovic, ${ }^{4}$ Scott R Weaver, ${ }^{1,5}$ \\ Jidong Huang, ${ }^{1,2}$ Michael P Eriksen ${ }^{1,2}$
}

\begin{abstract}
- Additional material is published online only. To view please visit the journal online (http://dx.doi.org/10.1136/ tobaccocontrol-2017-053734).
\end{abstract}

${ }^{1}$ Georgia State University's Tobacco Center of Regulatory Science, Atlanta, Georgia, USA ${ }^{2}$ Division of Health Management \& Policy, Georgia State University, Atlanta, Georgia, USA

${ }^{3}$ Public Health Research \& Translational Science, Battelle Memorial Institute, Atlanta, Georgia, USA

${ }^{4}$ Decision Research, Eugene, Oregon, USA

${ }^{5}$ Division of Epidemiology and Biostatistics, Georgia State University, Atlanta, Georgia, USA

\section{Correspondence to}

Dr Terry Frank Pechacek, School of Public Health, Tobacco Center of Regulatory Science, Georgia State University, Urban Life Building, Atlanta, Georgia 30303, USA;

tpechacek@gsu.edu

Received 1 March 2017 Revised 23 October 2017 Accepted 24 October 2017 Published Online First 28 November 2017

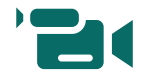

Watch Video www.goo.gl/Ag4Ep7

\section{ABSTRACT}

Introduction Benefit-cost analyses of tobacco regulations include estimates of the informed choice of smokers to continue smoking. Few studies have focused on subjective feelings associated with continued smoking. This study estimates how smoker discontent and regret relate to risk perceptions and health concerns. Methods We analysed data from a 2015 nationally representative, online survey of 1284 US adult current smokers. Information was collected on regret, intention to quit, perceived addiction, risk perceptions and health concerns. Multivariate logistic regression adjusting for sociodemographics and health status was used to examine factors associated with smoker discontent.

Results More than $80 \%$ of current smokers report high $(22.5 \%)$ or very high $(59.8 \%)$ discontent due to inability to quit, perceived addiction and regret about having started to smoke. Higher levels of discontent did not vary significantly by sex, age, race/ethnicity, education or income (adjusted odds ratios (AORs) 0.5-1.2). Compared with the smokers expressing low $(5.9 \%)$ or very low (3.6\%) discontent, those expressing higher levels of discontent perceived their health status as fair/poor $(A O R=2.3)$, worried most of the time about lung cancer $(A O R=4.6)$ and felt they were more likely to develop lung cancer in the future $(A O R=5.1)$.

Conclusion The proportion of smokers who might be characterised as having a preference to continue smoking are greatly outnumbered by addicted, discontent and concerned smokers who want to quit and regret ever having started to smoke. These discontent smokers could have a substantial net welfare gain if new regulations helped them escape their concerns about the health effects from continuing smoking.

\section{INTRODUCTION}

Tobacco control efforts in the USA continue to advance, and the prevalence of current cigarette smoking among adults and youth are at historic low levels. ${ }^{1-7}$ Effective implementation of federal regulations of cigarettes and tobacco products under the authority assigned to the Food and Drug Administration (FDA) by the 2009 Family Smoking Prevention and Tobacco Control Act (Tobacco Control $A c t)$ is important to sustain this progress. ${ }^{2}{ }^{8-11}$ FDA is required as part of the federal rule-making process to conduct an economic benefit-cost analysis of all proposed regulations. ${ }^{12}$ However, significant questions have been raised about how the benefit-cost analyses of the FDA regulation on tobacco products should be conducted. ${ }^{13-19}$ A final FDA rule requiring graphic warning labels on cigarette packaging has not been implemented in part due to concerns about the benefit-cost analysis presented in the draft rule. ${ }^{19-22}$ The benefit-cost analysis was based on widely accepted structural welfare analysis methods to quantify the utility with and without the proposed regulation. ${ }^{18} 192324$ Significant concerns were noted when this analysis indicated that the potential health benefits of implementing graphic warnings on US cigarette packages should be discounted by $50 \%$ or more due to 'lost pleasure' (ie, consumer surplus). ${ }^{13-17}$ Leading health economists were convened by the US Department of Health and Human Services to consider the recommended methods for calculating the economic impact of potential FDA regulatory actions on cigarettes or other tobacco products. ${ }^{131825}$ Subsequently, Cutler and colleagues offered four possible approaches to the contentious issue of estimating consumer surplus in benefit-cost analyses concerning addictive goods: (1) willingness to pay for cessation, (2) direct measurement of subjective well-being, (3) structural welfare analysis methods (like those used by FDA in the graphic warning labels analysis) ${ }^{19}$ and (4) rational benchmark. Of these approaches, Cutler and colleagues identified the 'Rational Benchmark' approach as the most feasible. The rational benchmark approach uses criterion (such as not showing high nicotine dependence and/ or having completed a college degree) to identify smokers who are more likely to be well informed and acting more rationally in making an informed choice to continue smoking. ${ }^{25-27}$ In a hypothetical regulation example, this approach suggested that the utility offsets to health benefits would be much smaller, in the range of 5\%-20\% and likely in the lower end of this range. ${ }^{18}$ However, much uncertainty remained in calculating the economic offset ratio using structural and rational benchmark approaches (eg, with possible offset ratios shown as varying from $0 \%$ to $50 \%){ }^{1925}$ Therefore, an alternative willingness-to-pay break-even approach was used in the recent final 'deeming' rule to assert FDA authority over all additional tobacco products not listed in the 2009 Tobacco Control Act, including cigars, pipe tobacco, waterpipe tobacco, electronic nicotine delivery systems and other novel tobacco products such as certain dissolvable products and gels. $^{28}$ Thus, the underlying logic of assessing tobacco regulations using methods grounded in rational choice theory still remains a controversial 
issue. ${ }^{13} 14$ 29-32 Evidence shows that both 'enjoyment' and 'relief from cravings' are often cited by smokers as the reasons they continue to smoke. ${ }^{33-35}$ However, as Schelling asserted, individuals effectively divide themselves into two conflicting selves. ${ }^{3637}$ The current rational choice theory approach only focuses on 'lost pleasure' from being induced to quit by a new regulation, while many, if not almost all, smokers without the inducement would continue to suffer a net welfare loss from their inability to stop smoking: they regret having started to smoke as adolescents and worry about dying prematurely from smoking, but they feel addicted and unable to quit. ${ }^{13-16} 29-3138-44$ While some evidence supports this position, ${ }^{32}$ there is little recent data describing which types of smokers in the USA express regret, nor how intention to quit, perceived addiction and health concerns relate to this regret.

In 2002, Action on Smoking and Health (ASH) based in the UK released a report highlighting that $83 \%$ of smokers expressed regret for having started to smoke and described smokers feeling misery, disgust and social stigma from their inability to quit smoking. ${ }^{45}$ In an editorial, Slovic reported data from an unpublished 2000-2001 survey in the USA indicating that more than $80 \%$ of current smokers reported that they would not start smoking if they had it to do over again. When asked 'why not', they expressed disgust and misery about their continuing smoking. ${ }^{30}$ Smoker regret in the USA has been assessed in the Gallup Poll, with $88 \%$ of smokers surveyed in 2012 indicating they wished they had never started. ${ }^{46}$ The most extensive data on regret have been reported by the International Tobacco Control Policy Evaluation Project (ITC), which has tracked a variety of perceptions among smokers in 20 countries (including feeling addicted, intentions to quit and regret over having started to smoke). ${ }^{40424347}$ Measurements of US smokers were reported across eight overlapping waves from 2002 to 2010-2011 and indicated that $88 \%-90 \%$ of smokers expressed regret over this period. ${ }^{47}$ However, there are only a limited number of analyses of these ITC data, with only one detailed analysis of US data from 2002. ${ }^{42} 43$ Fong and colleagues reported that 91.2\% of smokers from the USA agreed or strongly agreed that they regretted having started smoking, which was consistent with the high prevalence of regret reported in the unpublished UK ASH and Slovic estimates. ${ }^{29} 4045$ O'Connor and colleagues recently explored the relationships between smokers' feelings of regret and other characteristics such as delay discounting and worries about future health. ${ }^{48}$ They reported that among US adult smokers completing a 2010 web-based survey, $84.4 \%$ expressed regret and that regret was positively associated with worries about the negative impact of their smoking on health, quality of life and how much they spend on cigarettes. ${ }^{48}$ Finally, we recently reported that in $2014,71.5 \%$ of US adult smokers expressed regret and that older and non-Hispanic white smokers were most likely to report regret. ${ }^{44}$

This paper provides data from a 2015 nationally representative sample of US adult smokers that estimates the proportion of smokers who feel addicted, express an intention to quit smoking and regret having started. These three variables are evaluated together as an index of smokers' discontent with their smoking, and we examine how this index relates to perceived addiction and concerns about the health effects of smoking. This index could be a potential rational benchmark to estimate the proportion of smokers who may experience net welfare loss from implementation of a policy or regulation.

\section{METHODS}

Data were obtained from the 2015 Tobacco Products and Risk Perceptions Survey (TPRPS), a national, cross-sectional survey of US adults. The TPRPS was administered by the Georgia State University (GSU) Tobacco Center of Regulatory Science, and this study was approved by the GSU Institutional Review Board. A probability sample was drawn from GfK's KnowledgePanel, yielding a completion rate of $75 \%(n=6091)$ after inviting a total of 8135 KnowledgePanel members. An additional 40 respondents were excluded, a priori, because they refused to answer at least $50 \%$ of the survey questions, resulting in a final survey sample of 6051 participants. For the present study, we restricted the study sample to only current smokers $(n=1284)$. In order to adjust for sampling and non-sampling error, data were weighted using an iterative proportional fitting (ranking) procedure. Demographic and geographic distributions for sex, age, race/ethnicity, education, household income, census region, metropolitan area and internet access obtained from the March 2015 Current Population Survey were used as benchmarks for the survey weights.

\section{Measures}

\section{Cigarette smoking status}

Respondents who reported not having smoked at least 100 cigarettes in their lives were classified as never smokers. Of the remaining respondents, those who reported having smoked at least 100 cigarettes and reported currently smoking cigarettes 'every day' or 'some days' were classified as current smokers.

\section{Nicotine dependency and perceptions and beliefs of addictiveness}

Smoking level was assessed using an item that assessed how many cigarettes they smoked on an average day that they smoked. The responses were categorised as: 1-5 cigarettes/day, 6-10 cigarettes/day, 11-15 cigarettes/day and more than 15 cigarettes/ day. ${ }^{49}$ Time to first cigarette was measured using 'How soon after you wake do you use a tobacco or electronic vapor product' with the following response choices: 'within 5 min', ' $6-30 \mathrm{~min}$ ', '31-60 min' and 'after 60 min'. ${ }^{50}$ For some analyses, responses were dichotomised into 'equal to or less than $30 \mathrm{~min}$ ' and 'more than 30 min'. 51

Participants were asked if they considered themselves addicted to cigarettes, with response options: 'not at all', 'yes, somewhat addicted', 'yes, very addicted' and 'I don't know'. The 'I don't know' responses, which were a small number $(n=39)$, were excluded from the analysis. Respondents were also asked, 'To what extent, if at all, do you agree that nicotine is the main substance in tobacco that makes people become addicted to tobacco products?' using a 5-point Likert scale ('strongly disagree' to 'strongly agree') and 'I don't know' as response choices. For this study, we recoded responses as 'disagree', 'neither disagree nor agree' and 'agree' and excluded 'I don't know' $(n=120)$. Finally, we assessed their craving for cigarettes by asking, 'Do you ever have strong cravings to smoke cigarettes?'. Response options were 'yes', 'no' and 'I don't know' (excluded from analysis, $\mathrm{n}=45)$.

\section{Quit intention}

Quit intention was assessed by asking respondents about their plan for quitting smoking cigarettes. Responses of 'intend to quit in the next 7 days' and 'intend to quit in the next month' were combined into a single group 'Planning to quit in next 1 month', 'intend to quit in the next 6 months' and 'intend to quit in the next year' were combined into a single variable 'Planning to Quit 
in next $>1$ month to a year', whereas responses of 'intend to quit someday, but not within the next year' and 'never plan to quit' were maintained as separate categories.

\section{Smoker regret}

Regret from continued smoking was assessed by responses to the question, 'If I had it to do over again, I would not have started smoking cigarettes', on a 5-point Likert agreement scale ('strongly disagree' to 'strongly agree'). For most analyses in this study, responses were considered in three categories: with 'strongly disagree' or 'disagree' classified as not having smoker regret, 'neither disagree or agree' classified as neutral and 'agree' or 'strongly agree' classified as smoker regret. Respondents were subsequently asked 'Why did you answer that way?' in an openended question. To minimise response bias, questions about regret were separated from questions about health risk, quit intentions and addiction.

\section{Perceptions of lung cancer risk}

Respondents' perceptions of lung cancer risk were assessed by three items: (1) 'How likely do you think it is that you develop lung cancer in the future?'. Response choices were 'very unlikely', 'somewhat unlikely', 'neither unlikely nor likely', 'somewhat likely' and 'very likely'. For analyses, 'very (un)likely' and 'somewhat (un)likely' were collapsed into unlikely or likely categories, respectively. (2) 'Imagine the average cigarette smoker. How much higher is that person's risk of getting lung cancer, compared to those who have never used any tobacco or electronic vapor product?', and (3) 'How much higher is your risk of getting lung cancer, compared to those who have never used any tobacco or electronic vapor product?' These two items were measured using a 7-point response scale ranging from 'about the same' $(=0)$ to 'much higher' $(=6)$.

Respondent worry about lung cancer was assessed with, 'How often do you worry about getting lung cancer?'. Response options were 'rarely or never', 'sometimes', 'often' and 'all the time.' Respondent knowledge about the cure rate for lung cancer was assessed with, 'Overall, how many people who develop lung cancer do you think are cured?'. Response options were 'less than one quarter', 'about one quarter', 'about half', 'about three quarters' and 'nearly all'.

\section{Perceived health risks from smoking}

To assess respondents' perceptions of the health risks of smoking, they were asked to 'Imagine that you just began smoking cigarettes [every day or only once in a while, say at parties or with friends]. What do you think your chances are of having each of the following happen to you if you continue to smoke cigarettes [every day or only once in a while]?'. For each of every day or once in a while, they rated their perceived chances of 'lung cancer', 'lung disease other than lung cancer (such as COPD and emphysema)', 'heart disease', 'become addicted' and 'early/ premature death' on a 7-point response scale ranging from 'no chance' $(=0)$ to 'very good chance' $(=6)$. Responses of 'I don't know' were excluded from the analyses. In order to minimise possible bias due to question order, the order of these questions was randomised. Additionally, questions about behaviours were positioned early before attitudes and beliefs were assessed.

\section{Index of smokers' discontent}

For figure 1, the responses from items smoker regret, perceived addiction and intention to quit were used to create a classification grid to assign a score from $1=$ low discontent
Five Levels of Smoker's Discontent - Low to High

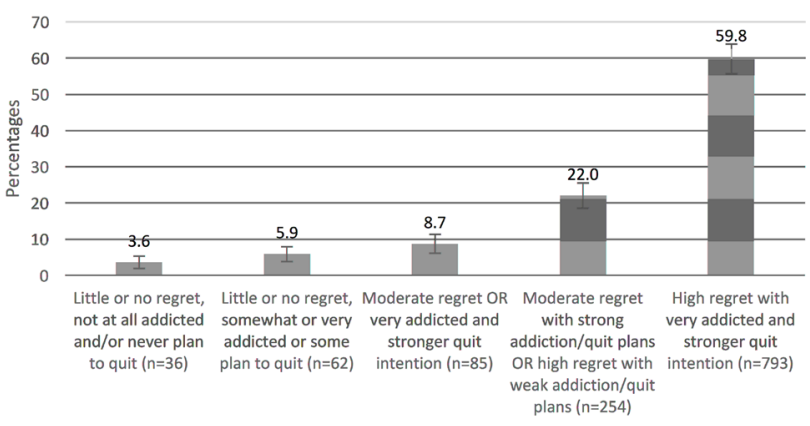

Figure 1 Rational benchmark estimates of smoker's discontent due to smoker regret, perceived addiction and intention to quit smoking. See online supplementary figure $\mathrm{S} 1$ for detailed classification of Levels of Discontent Index.

to $5=$ high discontent (see online supplementary figure S1). Smokers who reported not having smoker regret, never plan to quit and not at all addicted or somewhat addicted, or not at all addicted and plan to quit someday were classified as low discontent. Smokers who reported smoker regret and somewhat or very addicted and planned to quit in the next year or less were classified as high discontent. The three levels of perceived addiction $(1=$ not at all, $2=$ yes, somewhat addicted and $3=y e s$, very addicted) were combined with the four levels of intention to quit $(1=$ planning to quit in next 1 month, $2=$ planning to quit in next $>1$ month to a year, $3=$ intend to quit someday, but not within the next year and $4=$ never plan to quit) to create a four-level Quit+Addiction code: 1=(intent to quit=1 and addiction $=2$ or 3$) ; 1=($ intent to quit $=2$ and addiction $=3$ ); $2=($ intent to quit $=2$ and addiction $=2) ; 2=($ intent to quit $=3$ and addiction $=2$ or 3 ); $3=$ (intent to quit $=1$ or 2 and addiction $=1$ ); $3=($ intent to quit $=4$ and addiction $=3) ; 4=($ intent to quit $=3$ or 4 and addiction $=1)$; and $4=($ intent to quit $=4$ and addiction $=2$ ). Discontent index was coded as:

- $1=$ nothaving smoker regret ( 1 and 2 ) and Quit+Addiction $=4$.

- 2=not having smoker regret (1 and 2) and Quit+Addiction $=2$ or 3 .

- 3 =nothaving smoker regret (1 and 2 ) and Quit + Addiction $=1$.

- 3=neutral smoker regret (3) and Quit+Addiction $=3$ or 4.

- 4=neutral smoker regret (3) and Quit+Addiction $=1$ or 2 .

- 4=having smoker regret (4 and 5) and Quit+Addiction $=3$ or 4.

- 5=having smoker regret (4 and 5) and Quit+Addiction $=1$ or 2.

\section{Sociodemographics}

Respondents' sociodemographic characteristics were obtained from profile surveys administered by $\mathrm{GfK}^{52}$ to all KnowledgePanel panellists and included self-reported sex, age, race/ ethnicity, educational attainment, annual household income, region, health status and presence of children under 18 years old.

\section{STATISTICAL ANALYSIS}

All analyses were performed using the survey procedures within SAS (V,9.3); all results reported are weighted unless otherwise noted. We estimated the weighted proportions for key variables and used the Rao-Scott $\chi^{2}$ test to examine bivariate associations. Weighted survey means were obtained for continuous 


\begin{tabular}{|c|c|c|c|}
\hline Respondent characteristics & $\begin{array}{l}\text { Not at all addicted } \\
(\mathrm{n}=151) \%(95 \% \mathrm{Cl})\end{array}$ & $\begin{array}{l}\text { Yes, somewhat addicted } \\
(\mathrm{n}=509) \%(95 \% \mathrm{Cl})\end{array}$ & $\begin{array}{l}\text { Yes, very addicted } \\
(\mathrm{n}=579) \%(95 \% \mathrm{Cl})\end{array}$ \\
\hline \multicolumn{4}{|l|}{ Sex* } \\
\hline Male & 54.7 (43.7 to 65.8$)$ & 52.3 (46.0 to 58.5$)$ & 36.2 (30.7 to 41.7 ) \\
\hline Female & 45.3 (34.2 to 56.3 ) & 47.7 (41.5 to 54.0$)$ & 63.8 (58.3 to 69.3 ) \\
\hline $35-54$ & $36.8(25.7$ to 48.0$)$ & 40.0 (33.9 to 46.1$)$ & 37.1 (31.3 to 43.0$)$ \\
\hline$>55$ & 17.1 (9.5 to 24.8$)$ & 25.8 (21.1 to 30.6) & 37.3 (31.4 to 43.1 ) \\
\hline \multicolumn{4}{|l|}{ Race/ethnicity * } \\
\hline White, non-Hispanic & 44.3 (33.7 to 55.0$)$ & 54.5 (48.1 to 60.9$)$ & 74.4 (68.6 to 80.2) \\
\hline Other & 55.7 (45.0 to 66.3$)$ & 45.5 (39.1 to 51.9$)$ & 25.6 (19.8 to 31.4$)$ \\
\hline \multicolumn{4}{|l|}{ Household income } \\
\hline$<\$ 30000$ & 40.0 (28.9 to 51.2$)$ & 36.1 (29.9 to 42.2$)$ & 36.3 (30.3 to 42.3 ) \\
\hline$\$ 30000-\$ 60000$ & 21.3 (12.8 to 29.8$)$ & 29.1 (23.2 to 34.9$)$ & 26.4 (21.5 to 31.3$)$ \\
\hline$\$>60000$ & 38.7 (28.1 to 49.3 ) & 34.9 (29.1 to 40.6$)$ & 37.3 (31.5 to 43.1$)$ \\
\hline \multicolumn{4}{|l|}{ US region* } \\
\hline Northeast & 23.2 (13.6 to 32.7 ) & 13.4 (10.0 to 16.9$)$ & 13.9 (10.1 to 17.8$)$ \\
\hline Midwest & 15.4 (8.9 to 21.8$)$ & 23.1 (18.3 to 27.9$)$ & 30.4 (25.1 to 35.8$)$ \\
\hline South & 36.9 (25.8 to 47.9$)$ & 39.6 (33.3 to 46.0$)$ & 34.7 (28.8 to 40.6 ) \\
\hline West & 24.6 (15.3 to 33.8$)$ & 23.9 (18.3 to 29.4$)$ & 21.0 (16.0 to 25.9$)$ \\
\hline \multicolumn{4}{|l|}{ Perceived health status* } \\
\hline
\end{tabular}

data. Multivariate logistic regression models were estimated to examine predictors of smoker regret while adjusting for sociodemographic factors, including age, gender, ethnicity, annual income and health status. We performed data analyses with significance at $\mathrm{P}<0.05$ set a priori.

\section{RESULTS}

The smoking prevalence estimates by sex, age, race/ethnicity, US region of residence, perceived health status and presence of children under 18 years in the home are shown in online supplementary table S1A. Estimates from our surveys have been shown to agree with other nationally representative data. ${ }^{52}$

Table 1 provides estimates of smokers' perceived addiction to cigarettes by sex, age, education, race/ethnicity, US region of residence, perceived health status and presence of children under 18 years in the home. Over $80 \%$ of smokers perceive themselves as somewhat or very addicted to cigarettes. Female, older, white non-Hispanic smokers who reported poorer health status and from households without children under age 18 years perceived themselves as more addicted to cigarettes.

Table 2 provides estimates of smokers' intention to quit smoking by sex, age, race/ethnicity, US region of residence, perceived health status and presence of children under 18 years in the home. Intentions to quit were high across the demographic categories, with about 34\% (95\% CI 29.8 to 37.3 ) planning to quit at some time, and $35 \%$ planning to quit in the next year $(95 \%$ CI 31.5 to 39.0$)$. Intentions to quit were higher among smokers with more education and higher incomes.

Table 3 presents the weighted percentage of respondent characteristics by smokers' regret status measured as 'If you had it to do over again, you would not have started smoking'. More than $70 \%$ of smokers expressed regret about having started to smoke. Smokers' regret was high among all demographic groups and was higher among females, older and white non-Hispanic respondents and was highest among those reported a fair/poor perceived health status. Smokers self-reporting that they felt very addicted also expressed more regret (see online supplementary figure S2). Examples of open-ended responses to question about regret, 'Why did you answer that way?' are shown in online supplementary figure S3.

Figure 1 displays estimates for a possible 'rational benchmark' groups of smokers: namely, those that might be classified as making the choice to continue smoking (ie, lack of regret, perceiving to be not addicted to cigarettes and never planning to quit) versus the discontent smokers (ie, having regret, feeling addicted and wanting to quit in the next year or less). This latter group is very large $(59.8 \%)$, while those smokers who might be 
Table 2 Demographic characteristics of current smoker by their intention to quit status

\begin{tabular}{|c|c|c|c|c|}
\hline \multirow[b]{2}{*}{ Respondent characteristics } & \multicolumn{4}{|c|}{ Intention to quit (total $n=1279$ ) } \\
\hline & $\begin{array}{l}\text { Planning to quit in next } \\
1 \text { montht } \\
\text { (n=190) \% }(95 \% \mathrm{Cl})\end{array}$ & $\begin{array}{l}\text { Planning to quit in next }>1 \\
\text { month someday, but not to a } \\
\text { year ₹ } \\
(\mathrm{n}=458) \%(95 \% \mathrm{Cl})\end{array}$ & $\begin{array}{l}\text { Plan to quit someday, but } \\
\text { not within next year } \\
\text { (n=444) \% (95\% Cl) }\end{array}$ & $\begin{array}{l}\text { Never plan to quit } \\
(\mathrm{n}=187) \%(95 \% \mathrm{Cl})\end{array}$ \\
\hline Total & 16.1 (13.1 to 19.2$)$ & 35.2 (31.5 to 39.0$)$ & 33.5 (29.8 to 37.3$)$ & 15.1 (12.1 to 18.1$)$ \\
\hline \multicolumn{5}{|l|}{ Sex } \\
\hline Male & 15.6 (11.6 to 19.6$)$ & 34.2 (28.8 to 39.6$)$ & 33.4 (28.0 to 38.8 ) & 16.8 (12.2 to 21.5$)$ \\
\hline Female & $16.6(12.2$ to 21.0$)$ & 36.2 (30.9 to 41.4$)$ & 33.7 (28.5 to 38.9$)$ & 13.5 (9.7 to 17.4$)$ \\
\hline \multicolumn{5}{|l|}{ Age (years) } \\
\hline $18-34$ & $15.9(10.7$ to 21.1$)$ & $37.0(29.9$ to 44.1$)$ & 34.5 (27.5 to 41.5$)$ & $12.6(7.6$ to 17.7$)$ \\
\hline $35-54$ & 18.2 (12.6 to 23.7$)$ & 35.7 (29.7 to 41.7$)$ & $34.0(27.9$ to 40.1$)$ & 12.1 (7.4 to 16.9$)$ \\
\hline$>55$ & 13.7 (9.4 to 18.0$)$ & 32.5 (26.1 to 38.9$)$ & 31.7 (25.5 to 37.9$)$ & 22.1 (16.3 to 27.9$)$ \\
\hline \multicolumn{5}{|l|}{ Race/ethnicity } \\
\hline White, non-Hispanic & 15.7 (12.1 to 19.3$)$ & 36.0 (31.6 to 40.3$)$ & 34.1 (29.8 to 38.4$)$ & $14.3(11.3$ to 17.3$)$ \\
\hline Other & 16.9 (11.6 to 22.2$)$ & $34.1(27.3$ to 41.0$)$ & 32.7 (25.8 to 39.5$)$ & $16.3(10.3$ to 22.4$)$ \\
\hline \multicolumn{5}{|l|}{ Education $*$} \\
\hline High school or less & $14.7(10.4$ to 18.9$)$ & 32.3 (27.0 to 37.6$)$ & 36.6 (31.2 to 42.1$)$ & 16.4 (12.0 to 20.8$)$ \\
\hline Some college & $15.0(10.0$ to 20.0$)$ & 40.5 (33.8 to 47.2$)$ & 32.8 (26.3 to 39.2$)$ & 11.7 (7.3 to 16.1$)$ \\
\hline College degree+ & 23.8 (16.2 to 31.3$)$ & 36.2 (27.9 to 44.5$)$ & $23.4(16.8$ to 30.0$)$ & 16.7 (9.4 to 24.0$)$ \\
\hline \multicolumn{5}{|l|}{ Household income $*$} \\
\hline$<\$ 30000$ & 17.7 (12.0 to 23.3$)$ & $28.3(22.5$ to 34.1$)$ & $35.0(28.5$ to 41.5$)$ & 19.1 (13.1 to 25.0$)$ \\
\hline$\$ 30000-\$ 60000$ & $10.7(6.6$ to 14.9$)$ & $36.6(29.3$ to 43.9$)$ & $37.8(30.4$ to 45.1$)$ & $14.9(9.5$ to 20.4$)$ \\
\hline$\$>60000$ & 18.6 (13.6 to 23.7$)$ & 41.4 (35.1 to 47.7$)$ & 28.9 (23.1 to 34.6$)$ & 11.1 (7.4 to 14.8$)$ \\
\hline \multicolumn{5}{|l|}{ US region } \\
\hline Northeast & 16.6 (9.9 to 23.2 ) & 38.5 (29.5 to 47.5$)$ & 34.5 (25.5 to 43.6$)$ & $10.4(5.3$ to 15.4$)$ \\
\hline Midwest & $17.2(11.8$ to 22.6$)$ & $33.8(27.2$ to 40.4$)$ & 34.8 (28.1 to 41.4$)$ & $14.3(9.0$ to 19.5$)$ \\
\hline South & $13.8(8.7$ to 18.9$)$ & 35.5 (28.7 to 42.2$)$ & $35.0(28.1$ to 41.9$)$ & 15.7 (10.3 to 21.2$)$ \\
\hline West & 18.5 (11.5 to 25.4$)$ & $34.3(26.3$ to 42.4$)$ & 29.3 (22.1 to 36.6$)$ & $17.9(11.0$ to 24.7$)$ \\
\hline \multicolumn{5}{|l|}{ Perceived health status } \\
\hline Excellent/very good & $18.8(13.6$ to 24.0$)$ & $33.6(27.4$ to 39.9$)$ & 34.4 (28.4 to 40.4$)$ & 13.1 (8.6 to 17.7$)$ \\
\hline Good & $14.0(9.5$ to 18.4$)$ & $35.2(29.5$ to 41.0$)$ & $36.0(30.0$ to 42.1$)$ & $14.8(10.3$ to 19.3$)$ \\
\hline Fair/poor & 15.3 (8.9 to 21.8$)$ & 38.4 (29.9 to 46.8$)$ & $29.3(21.5$ to 37.1$)$ & $17.0(10.1$ to 23.9$)$ \\
\hline \multicolumn{5}{|c|}{ Presence of children under 18 years in the household } \\
\hline Yes & 17.2 (11.9 to 22.4$)$ & $35.9(29.4$ to 42.3$)$ & $33.6(27.0$ to 40.2$)$ & 13.4 (8.2 to 18.6$)$ \\
\hline No & 15.6 (11.9 to 19.3$)$ & 34.9 (30.3 to 39.6$)$ & 33.5 (28.9 to 38.0$)$ & 15.9 (12.3 to 19.6$)$ \\
\hline
\end{tabular}

${ }^{*} \mathrm{P}<0.05$.

†Combined 'intend to quit in the next 7 days' and 'intend to quit in the next month'.

$\neq$ Combined 'intend to quit in the next 6 months' and 'intend to quit in the next year'.

classified as having no regret and no plan to quit smoking is considerably smaller (3.6\%).

Table 4 presents demographics, perceived nicotine dependency and perceived lung cancer risk and worry by discontent level. Respondents classified as having 'low discontent' (rated 1 or 2) were compared with those with 'moderate' (rated 3) or 'high' (rated 4 or 5) discontent. Adjusted ORs (AORs) were computed by multivariable logistic regression, adjusting for gender, age, race/ethnicity, household income and perceived health status. Respondents reporting having their first smoke after $30 \mathrm{~min}$ compared with those who smoke within $30 \mathrm{~min}$ are less likely to report having high discontent level $(\mathrm{AOR}=0.4$, $95 \%$ CI 0.2 to 0.9 ). Smokers who are more likely to perceive that they will develop lung cancer in the future compared with those who perceive themselves less likely had higher odds for experiencing high discontent (AOR 5.1, 95\% CI 2.2 to 12.0). Online supplementary figure $\mathrm{S} 2$ provides additional perceived risk for other smoking-related health conditions by discontent index. Smokers experiencing high discontent also felt they had a higher chance of early or premature death if they continued to smoke every day.

\section{DISCUSSION}

Among this nationally representative sample of current adult smokers in the USA, only a very small proportion report they did not plan to quit sometime in the future, did not consider themselves addicted to cigarettes and did not express regret for having started to smoke. Not only do a high proportion of smokers by sex, age, race/ethnicity, education and household income commonly perceive themselves as addicted to cigarettes and express regret for having started to smoke, but these smokers rate their worry and concern as higher for dying from lung cancer and premature death. These perceptions together with the expressed negative feelings about why they regret having started smoking (see reported feelings in online supplementary figure S3) agree with what the ASH survey and Slovic have called a picture of misery. ${ }^{3045}$ Thus, within the rational benchmark approach suggested by Cutler 
Table 3 Demographic and other characteristics by smokers regret status, 2015 ( $n=1276)$

\begin{tabular}{|c|c|c|c|c|c|}
\hline $\begin{array}{l}\text { Respondent } \\
\text { characteristics }\end{array}$ & $\begin{array}{l}\text { Respondents who } \\
\text { strongly disagreed for } \\
\text { having regret } \dagger \\
\mathrm{n}=54 \%(95 \% \mathrm{Cl})\end{array}$ & $\begin{array}{l}\text { Respondents who } \\
\text { disagreed for having } \\
\text { regrett } \\
\mathrm{n}=61 \%(95 \% \mathrm{Cl})\end{array}$ & $\begin{array}{l}\text { Respondents who had } \\
\text { a neutral opinion for } \\
\text { having regret } \dagger \\
n=183 \%(95 \% \mathrm{Cl})\end{array}$ & $\begin{array}{l}\text { Respondents who agreed } \\
\text { for having regrett } \\
n=250 \%(95 \% \mathrm{Cl})\end{array}$ & $\begin{array}{l}\text { Respondents who } \\
\text { strongly agreed for } \\
\text { having regret } \dagger \\
n=728 \%(95 \% \mathrm{Cl})\end{array}$ \\
\hline \multicolumn{6}{|l|}{ Demographic } \\
\hline \multicolumn{6}{|l|}{$\mathrm{Sex}^{*}$} \\
\hline Male & $3.1(1.2$ to 4.9$)$ & 6.1 (2.9 to 9.3$)$ & 24.3 (18.7 to 29.9$)$ & 19.8 (15.6 to 24.1$)$ & 46.7 (41.0 to 52.3$)$ \\
\hline \multicolumn{6}{|l|}{ Age (years)* } \\
\hline $18-34$ & 4.9 (1.7 to 8.2$)$ & 4.9 (1.8 to 8.0$)$ & 26.3 (19.3 to 33.3$)$ & 19.7 (13.7 to 25.7 ) & 44.2 (37.0 to 51.4$)$ \\
\hline $35-54$ & $2.8(1.3$ to 4.3$)$ & 8.4 (4.0 to 12.8$)$ & $15.7(10.4$ to 21.0$)$ & 17.7 (12.8 to 22.6$)$ & $55.4(48.8$ to 62.0$)$ \\
\hline$>55$ & $5.8(2.1$ to 9.5$)$ & 3.4 (1.4 to 5.3$)$ & $11.6(7.4$ to 15.7$)$ & 19.7 (14.9 to 24.6$)$ & 59.6 (53.1 to 66.0$)$ \\
\hline \multicolumn{6}{|l|}{ Race/ethnicity* } \\
\hline White, non-Hispanic & $3.6(2.0$ to 5.1$)$ & 4.8 (2.8 to 6.8$)$ & 15.3 (11.7 to 18.9$)$ & 20.8 (17.1 to 24.4$)$ & 55.6 (51.0 to 60.2$)$ \\
\hline Some college & $2.9(0.9$ to 4.9$)$ & 8.2 (3.7 to 12.6$)$ & 18.4 (12.5 to 24.4$)$ & 19.5 (14.2 to 24.8$)$ & 51.1 (44.1 to 58.0$)$ \\
\hline College degree+ & $3.8(0.6$ to 7.0$)$ & 10.1 (3.2 to 16.9$)$ & $18.5(10.7$ to 26.3$)$ & 22.8 (16.4 to 29.2 ) & 44.8 (36.4 to 53.2 ) \\
\hline \multicolumn{6}{|l|}{ Household income } \\
\hline$<\$ 30000$ & 6.7 (3.0 to 10.4$)$ & $3.7(0.7$ to 6.6$)$ & $19.0(13.2$ to 24.7$)$ & $17.0(11.7$ to 22.3$)$ & 53.6 (46.7 to 60.6$)$ \\
\hline$\$ 30000-\$ 60000$ & 3.5 (1.3 to 5.6$)$ & 7.1 (2.6 to 11.6$)$ & 15.0 (9.0 to 21.0$)$ & 16.2 (10.9 to 21.5$)$ & 58.2 (50.7 to 65.8 ) \\
\hline$\$>60000$ & 2.6 (0.8 to 4.5$)$ & 7.0 (3.5 to 10.5$)$ & $19.7(13.9$ to 25.5$)$ & 22.9 (17.7 to 28.2$)$ & 47.7 (41.3 to 54.0$)$ \\
\hline \multicolumn{6}{|l|}{ US region } \\
\hline Northeast & $1.7(0.2$ to 3.3$)$ & 6.5 (0.7 to 12.2$)$ & 15.4 (8.3 to 22.4$)$ & 22.4 (14.4 to 30.4$)$ & 54.1 (44.7 to 63.4$)$ \\
\hline Midwest & $4.1(1.3$ to 6.9$)$ & 2.6 (0.8 to 4.4$)$ & 14.5 (9.1 to 19.9$)$ & 22.4 (16.5 to 28.3$)$ & 56.4 (49.3 to 63.5$)$ \\
\hline South & 5.7 (2.1 to 9.3$)$ & 6.9 (3.1 to 10.7$)$ & 21.5 (14.9 to 28.0$)$ & 15.1 (9.8 to 20.4 ) & 50.8 (43.6 to 58.0$)$ \\
\hline West & 4.1 (1.6 to 6.7$)$ & $7.0(2.1$ to 11.9$)$ & 18.7 (11.7 to 25.7$)$ & $19.2(13.1$ to 25.3$)$ & 51.0 (42.5 to 59.4$)$ \\
\hline
\end{tabular}

${ }^{*} \mathrm{P}<0.05$.

tHaving regret is defined by responses on question item 'If I had it to do over again, I would not have started smoking cigarettes. How much do you agree or disagree with this statement?' Response options were: strongly disagree, somewhat disagree, neither disagree nor agree, somewhat agree and strongly agree.

and colleagues as the most feasible for estimating the benefitcost of tobacco regulations, ${ }^{27}$ the findings shown in figure 1 suggest that the proportion of smokers who might be characterised as having a preference to continue smoking would be greatly outnumbered by the addicted, discontent and concerned smokers who want to quit and regret ever having started to smoke. Furthermore, these findings suggest that the second approach considered by Cutler and colleagues, namely measuring what happens to smokers' subjective well-being when they quit smoking, should receive greater attention. As noted by Cutler and colleagues and in recent research, ${ }^{27}{ }^{32}$ there are limited cohort data showing that subjective well-being increased among smokers who quit ${ }^{53}$; however, ex-smokers do report being happier. ${ }^{54-59}$ Concerns about the methodology of quantifying such changes in subjective well-being into monetary values are relevant. ${ }^{6061}$ However, if it is accurate, as suggested by our results, then the number of smokers who may be considered as having some net welfare loss from a new regulation is very small. The number of smokers who would have a substantial net welfare gain (even if difficult to quantify) by being helped by the new regulation in escaping the state of misery from continuing smoking is much larger. This suggests that the provisions within Office of Management and Budget Circular A-4 would justify excluding an adjustment for consumer surplus from the benefit-cost analyses of new FDA regulations of cigarettes and/or giving greater emphasis to the social welfare gains of quitting. ${ }^{12} 14$

\section{LIMITATIONS}

First, the use of the internet panel may raise concerns about sample representativeness, especially if the panel has been used in prior tobacco research. Mitigating this concern, however, is internal research by GfK that suggests minimal panel conditioning from participation in prior tobacco research. ${ }^{62}$ Second, the data are based on self-report, and biochemical verification of cigarette smoking and use of other products could not be conducted; however, the validity of self-reported cigarette smoking in surveys has been confirmed. ${ }^{2} 63$ 
Table 4 Demographic and other characteristics by smokers' discontent level* $(n=1230)$

\begin{tabular}{|c|c|c|c|c|c|}
\hline $\begin{array}{l}\text { Respondent } \\
\text { characteristics }\end{array}$ & $\begin{array}{l}\text { Respondents who } \\
\text { indicated having low } \\
\text { level of discontent } \\
(\mathrm{n}=98) \\
\%(95 \% \mathrm{Cl})\end{array}$ & $\begin{array}{l}\text { Respondents who } \\
\text { indicated having } \\
\text { moderate level of } \\
\text { discontent }(n=85) \\
\%(95 \% \mathrm{Cl}) \\
\end{array}$ & $\begin{array}{l}\text { Respondents who } \\
\text { indicated having high } \\
\text { level of discontent } \\
(\mathrm{n}=1047) \\
\%(95 \% \mathrm{Cl})\end{array}$ & $\begin{array}{l}\text { Adjusted OR for having } \\
\text { moderate discontent (low } \\
\text { is reference) } \dagger \\
\mathrm{AOR}(95 \% \mathrm{Cl})\end{array}$ & $\begin{array}{l}\text { Adjusted OR for having } \\
\text { high discontent (low is } \\
\text { reference) } \dagger \\
\text { AOR }(95 \% \mathrm{Cl})\end{array}$ \\
\hline \multicolumn{6}{|l|}{ Demographic } \\
\hline \multicolumn{6}{|l|}{ Sex* } \\
\hline Male & 8.5 (4.9 to 12.1$)$ & 12.9 (8.3 to 17.5$)$ & 78.6 (73.2 to 84.0$)$ & Reference & Reference \\
\hline Female & $10.3(6.7$ to 14.0$)$ & 5.1 (2.5 to 7.7$)$ & 84.6 (80.3 to 88.9 ) & $0.3(0.1 \text { to } 0.8)^{*}$ & 0.9 (0.5 to 1.6$)$ \\
\hline \multicolumn{6}{|l|}{ Age (years) } \\
\hline 18-34 & 8.5 (4.3 to 12.8$)$ & 13.3 (7.7 to 19.0$)$ & 78.1 (71.5 to 84.8$)$ & Reference & Reference \\
\hline $35-54$ & $10.8(6.2$ to 15.5$)$ & 7.7 (3.4 to 11.9 ) & 81.5 (75.6 to 87.4) & 0.5 (0.2 to 1.4$)$ & 0.7 (0.4 to 1.5$)$ \\
\hline$>55$ & 8.7 (4.6 to 12.8 ) & 4.9 (2.5 to 7.2$)$ & 86.4 (81.8 to 91.1$)$ & 0.6 (0.2 to 1.6$)$ & 1.2 (0.6 to 2.5 ) \\
\hline \multicolumn{6}{|l|}{ Race/ethnicity* } \\
\hline White, non-Hispanic & 8.4 (5.8 to 10.9$)$ & 6.0 (3.6 to 8.4) & 85.6 (82.3 to 89.0$)$ & Reference & Reference \\
\hline Other & $11.3(6.0$ to 16.5$)$ & 13.0 (7.5 to 18.5$)$ & 75.7 (68.8 to 82.7$)$ & $1.2(0.5$ to 3.0$)$ & 0.7 (0.4 to 1.4$)$ \\
\hline \multicolumn{6}{|l|}{ Education } \\
\hline High school or less & 7.8 (4.5 to 11.0$)$ & 9.9 (6.0 to 13.8$)$ & 82.3 (77.6 to 87.1$)$ & Reference & Reference \\
\hline Some college & 10.5 (5.7 to 15.4$)$ & $5.1(2.2$ to 8.0$)$ & 84.4 (78.9 to 89.8$)$ & $0.2(0.1 \text { to } 0.6)^{*}$ & 0.7 (0.3 to 1.4$)$ \\
\hline College degree+ & 13.7 (6.2 to 21.2$)$ & 11.1 (4.4 to 17.7 ) & 75.2 (66.3 to 84.2 ) & 0.5 (0.1 to 1.8$)$ & $0.5(0.2$ to 1.1$)$ \\
\hline \multicolumn{6}{|l|}{ Household income } \\
\hline$<\$ 30000$ & 8.7 (4.3 to 13.2 ) & 12.1 (7.0 to 17.2 ) & 79.1 (72.8 to 85.4 ) & Reference & Reference \\
\hline$\$ 30000-\$ 60000$ & 10.1 (5.1 to 15.2$)$ & 4.9 (1.6 to 8.2 ) & 84.9 (79.2 to 90.7$)$ & 0.3 (0.1 to 0.8 ) & 0.8 (0.3 to 1.6$)$ \\
\hline$\$>60000$ & 9.7 (5.7 to 13.7) & 8.0 (3.9 to 12.2 ) & 82.2 (76.8 to 87.6 ) & 0.4 (0.1 to 1.3$)$ & 0.8 (0.4 to 1.8$)$ \\
\hline \multicolumn{6}{|l|}{ Perceived health* } \\
\hline Excellent/very good & 12.5 (7.5 to 17.5$)$ & 13.2 (8.1 to 18.2 ) & 74.3 (67.9 to 80.7$)$ & Reference & Reference \\
\hline Good & 7.3 (4.2 to 10.4$)$ & 7.5 (3.4 to 11.5$)$ & 85.2 (80.4 to 90.1 ) & $1.1(0.4$ to 3.0$)$ & $2.0(1.0 \text { to } 3.9)^{*}$ \\
\hline Fair/poor & $6.6(1.9$ to 11.2$)$ & $2.9(0.9$ to 4.9$)$ & 90.6 (85.5 to 95.6) & $0.5(0.1$ to 1.5$)$ & $2.3(1.0$ to 5.5$)$ \\
\hline \multicolumn{6}{|c|}{ Presence of children under 18 years in the household } \\
\hline No & $8.8(5.8$ to 11.9$)$ & $8.4(5.3$ to 11.6$)$ & 82.7 (78.6 to 86.9$)$ & Reference & Reference \\
\hline Yes & $10.8(6.0$ to 15.6$)$ & $9.2(4.8$ to 13.7$)$ & 80.0 (73.9 to 86.1$)$ & $0.8(0.3$ to 2.3$)$ & $1.0(0.5$ to 1.9$)$ \\
\hline \multicolumn{6}{|l|}{ Nicotine dependency } \\
\hline \multicolumn{6}{|l|}{ Cigarettes smoked per day* } \\
\hline $1-5$ & $15.7(9.2$ to 22.2$)$ & 14.8 (8.6 to 21.0$)$ & 69.5 (61.6 to 77.4$)$ & Reference & Reference \\
\hline $6-10$ & 7.5 (3.6 to 11.5$)$ & $6.6(2.9$ to 10.3$)$ & $85.9(80.7$ to 91.1$)$ & $0.9(0.3$ to 2.7$)$ & $2.5(1.1 \text { to } 5.4)^{*}$ \\
\hline $11-15$ & $3.6(0.6$ to 6.6$)$ & $5.4(0.2$ to 10.7$)$ & $91.0(85.1$ to 96.9$)$ & $1.8(0.4$ to 8.3$)$ & $5.0(1.8 \text { to } 13.9)^{*}$ \\
\hline$>15$ & $7.8(4.1$ to 11.6$)$ & $5.8(1.6$ to 10.1$)$ & $86.3(80.9$ to 91.8$)$ & $0.9(0.3$ to 2.9$)$ & $2.2(1.0 \text { to } 4.8)^{*}$ \\
\hline \multicolumn{6}{|c|}{ Time after waking until first cigarette: how soon after waking do you usually have your first smoke?* } \\
\hline Within $30 \mathrm{~min}$ & $6.8(3.9$ to 9.7$)$ & $7.3(3.9$ to 10.8$)$ & $85.9(81.6$ to 90.2$)$ & Reference & Reference \\
\hline$>30 \min$ & $12.8(8.3$ to 17.3$)$ & $10.0(5.9$ to 14.0$)$ & 77.2 (71.7 to 82.8$)$ & $0.7(0.2$ to 1.8$)$ & $0.4(0.2 \text { to } 0.9)^{*}$ \\
\hline \multicolumn{6}{|c|}{ Perceived addiction to cigarettes } \\
\hline \multicolumn{6}{|c|}{ To what extent, if at all, do you agree that nicotine is the main substance in tobacco that makes people become addicted to tobacco products?* } \\
\hline Disagree & $18.9(8.3$ to 29.4$)$ & $8.8(1.0$ to 16.6$)$ & $72.4(60.6$ to 84.1$)$ & Reference & Reference \\
\hline $\begin{array}{l}\text { Neither disagree nor } \\
\text { agree }\end{array}$ & $10.2(1.4$ to 19.0$)$ & $15.2(5.2$ to 25.3$)$ & 74.6 (62.4 to 86.8) & $3.7(0.6$ to 22.3$)$ & $1.4(0.5$ to 4.4$)$ \\
\hline Agree & $8.1(5.3$ to 10.8$)$ & 6.7 (4.0 to 9.4$)$ & $85.3(81.6$ to 88.9$)$ & $1.9(0.4$ to 8.4$)$ & $1.9(0.9$ to 4.1$)$ \\
\hline \multicolumn{6}{|c|}{ Do you ever have strong cravings to smoke cigarettes?* } \\
\hline No & $13.2(7.1$ to 19.3$)$ & 20.5 (12.9 to 28.0$)$ & 66.3 (57.8 to 74.8$)$ & Reference & Reference \\
\hline Yes & $8.5(5.6$ to 11.4$)$ & $4.7(2.5$ to 7.0$)$ & $86.8(83.3$ to 90.3$)$ & $0.3(0.1 \text { to } 0.8)^{*}$ & $2.0(1.1 \text { to } 3.8)^{*}$ \\
\hline \multicolumn{6}{|c|}{ Perceptions of lung cancer risk } \\
\hline \multicolumn{6}{|c|}{ How likely do you think it is that you will develop lung cancer in the future?* } \\
\hline Unlikely & $18.4(10.8$ to 25.9$)$ & $15.1(8.5$ to 21.7$)$ & 66.6 (57.8 to 75.3$)$ & Reference & Reference \\
\hline Neither unlikely nor likely & $8.2(4.5$ to 11.8$)$ & $10.4(5.8$ to 15.1$)$ & 81.4 (75.8 to 86.9$)$ & $2.0(0.7$ to 5.5$)$ & $2.9(1.3 \text { to } 6.3)^{*}$ \\
\hline Likely & $6.0(2.7$ to 9.4$)$ & 3.8 (0.8 to 6.8$)$ & 90.2 (85.8 to 94.5$)$ & $1.3(0.4$ to 4.6$)$ & $5.1(2.2 \text { to } 12.0)^{*}$ \\
\hline \multicolumn{6}{|l|}{ Lung cancer worry } \\
\hline \multicolumn{6}{|c|}{ How often do you worry about lung cancer?* } \\
\hline Rarely or never & $12.8(8.0$ to 17.6$)$ & 13.9 (8.9 to 18.9$)$ & $73.3(66.9$ to 79.7$)$ & Reference & Reference \\
\hline Sometimes & $10.4(6.0$ to 14.8$)$ & $5.2(2.1$ to 8.3$)$ & 84.4 (79.3 to 89.5$)$ & $0.4(0.2 \text { to } 0.9)^{*}$ & $1.5(0.8$ to 2.8$)$ \\
\hline
\end{tabular}




\begin{tabular}{|c|c|c|c|c|c|}
\hline $\begin{array}{l}\text { Respondent } \\
\text { characteristics }\end{array}$ & $\begin{array}{l}\text { Respondents who } \\
\text { indicated having low } \\
\text { level of discontent } \\
(\mathrm{n}=98) \\
\%(95 \% \mathrm{Cl})\end{array}$ & $\begin{array}{l}\text { Respondents who } \\
\text { indicated having } \\
\text { moderate level of } \\
\text { discontent }(n=85) \\
\%(95 \% \mathrm{Cl})\end{array}$ & $\begin{array}{l}\text { Respondents who } \\
\text { indicated having high } \\
\text { level of discontent } \\
(\mathrm{n}=1047) \\
\%(95 \% \mathrm{Cl})\end{array}$ & $\begin{array}{l}\text { Adjusted OR for having } \\
\text { moderate discontent (low } \\
\text { is reference) } \dagger \\
\text { AOR }(95 \% \mathrm{Cl})\end{array}$ & $\begin{array}{l}\text { Adjusted OR for having } \\
\text { high discontent (low is } \\
\text { reference) } \dagger \\
\text { AOR }(95 \% \mathrm{Cl})\end{array}$ \\
\hline Often or all of the time & $4.8(0.8$ to 8.7$)$ & $6.4(1.1$ to 11.7$)$ & $88.8(82.4$ to 95.1 & 1.5 (0.4 to 6.8$)$ & $4.6(1.7 \text { to } 12.4)^{*}$ \\
\hline \multicolumn{6}{|c|}{ Overall, how many people who develop lung cancer do you think are cured?* } \\
\hline Less than one quarter & $10.2(6.1$ to 14.2$)$ & 5.7 (3.1 to 8.2$)$ & 84.2 (79.6 to 88.8$)$ & Reference & Reference \\
\hline $\begin{array}{l}\text { About one quarter to } \\
\text { about half }\end{array}$ & 10.3 (4.8 to 15.8$)$ & $5.6(1.4$ to 9.9$)$ & 84.1 (77.5 to 90.6$)$ & $0.7(0.2$ to 2.0$)$ & $0.9(0.5$ to 1.8$)$ \\
\hline About half to nearly all & $8.2(3.9$ to 12.5$)$ & 15.3 (8.7 to 21.8 ) & $76.5(69.3$ to 83.8$)$ & $3.3(1.2$ to 8.7$)$ & $1.3(0.7$ to 2.7$)$ \\
\hline
\end{tabular}

\section{${ }^{*} \mathrm{P}<0.05$.}

tDiscontent index: the responses from items smoker regret, perceived addiction and intention to quit was used to create a classification grid to assign a score from $1=$ low discontent to $5=$ high discontent (see online supplementary figure S1). Levels \#1 and \#2 are combined as Low, Level \#3 is Moderate, and Levels \#4 and \#5 are combined as High for the multinomial logistic analyses.

Third, question order and placement can produce potential response bias in assessment of risk perceptions and regret. To mitigate this concern, the questionnaire was structured to separate regret assessments from other measures of risk and product use.

\section{CONCLUSION}

Among this nationally representative sample of current adult smokers in the USA, only a very small proportion report they did not plan to quit sometime in the future, did not consider themselves addicted to cigarettes and did not express regret for having started to smoke. Thus, these results suggest that a large proportion of smokers could have a substantial net welfare gain with new regulation that enable them to escape the state of misery from continuing smoking. Hence, estimating net welfare gain rather than consumer welfare loss should be emphasised in policy analyses.

Acknowledgements The authors acknowledge the editorial assistance from Amelia Jazwa.

\section{What this paper adds}

- There is significant debate about how the benefit-cost analysis of tobacco regulations in the USA should be conducted.

- A 'rational benchmark' approach has been recommended to replace the standard structural welfare analysis (eg, estimating consumer surplus or 'lost pleasure') grounded in rational choice theory.

- Limited data are available to define preference to continue smoking based on subjective feelings of regret about having started to smoke, discontent with inability to quit and perceived risk of disease and premature death caused by continuing to smoke.

- Most smokers report feeling addicted, discontent and concerned and therefore want to quit and regret ever having started to smoke. The proportion of smokers reporting no regret about having started to smoke, not feeling addicted and never planning to quit is very small.

- The study findings support the inclusion of a reduction in smokers' discontent and an improvement in subjective wellbeing in cost and benefit analyses of the economic impact of tobacco regulations.
Contributors TFP and PN designed the study and conceptualised the data analysis. PN analysed the data. All authors contributed to interpretation. TFP, PN, SRW, PS and $\mathrm{JH}$ contributed to writing and reviewing drafts of manuscript. MPE assisted with the design of the parent study, reviewed drafts of the manuscript and providing critically input on design of the figures.

Funding This study was supported by grant number P50DA036128 from the National Institutes of Health, National Institute on Drug Abuse and Food and Drug Administration, Center for Tobacco Products. The author MPE receives funding from Pfizer, and all other authors of this paper report no other financial disclosures.

Disclaimer The content is solely the responsibility of the authors and does not necessarily represent the official views of the NIH or the Food and Drug Administration.

Competing interests None declared.

Ethics approval The study was approved by the Georgia State University's Institutional Review Boards (GSU IRB\# H14028) and Federal Wide Assurance Number 00000129.

Provenance and peer review Not commissioned; externally peer reviewed.

Open access This is an open access article distributed in accordance with the Creative Commons Attribution Non Commercial (CC BY-NC 4.0) license, which permits others to distribute, remix, adapt, build upon this work non-commercially, and license their derivative works on different terms, provided the original work is properly cited and the use is non-commercial. See: http://creativecommons.org/ licenses/by-nc/4.0/

(C) Article author(s) (or their employer(s) unless otherwise stated in the text of the article) 2018. All rights reserved. No commercial use is permitted unless otherwise expressly granted.

\section{REFERENCES}

1 Phillips E, Wang TW, Husten CG, et al. Tobacco product use among adults--United States, 2015. MMWR Morb Mortal Wkly Rep 2017:66:1209-15.

2 U.S. Department of Health \& Humans Services. The health consequences of smoking - 50 years of progress: a report of the surgeon general. Atlanta, GA: Department of Health and Human Services, National Center for Chronic Disease Prevention and Health Promotion, Office on Smoking and Health, 2014.

3 Arrazola RA, Singh T, Corey CG, et al. Tobacco use among middle and high school students - United States, 2011-2014. MMWR Morb Mortal Wkly Rep 2015;64:381-5.

4 Jamal A, Agaku IT, O'Connor E, et al. Current cigarette smoking among adults--United States, 2005-2013. MMWR Morb Mortal Wkly Rep 2014;63:1108-12.

5 Kann L, McManus T, Harris WA, et al. Youth risk behavior surveillance - United States, 2015. MMWR Surveill Summ 2016;65:1-174.

6 Singh T, Arrazola RA, Corey CG, et al. Tobacco use among middle and high school students--United States, 2011-2015. MMWR Morb Mortal Wkly Rep 2016;65:361-7.

7 Johnson LD, OMalley PM, Miech RA, et al. Monitoring the futurenational survey results on drug use, 1975-2015: overview, key findings on adolescent drug use. Ann Arbor, Michigan: Institute for Social Research, University of Michigan, 2016.

8 Zeller M. Reflections on the 'endgame' for tobacco control. Tob Control 2013;22(suppl 1):i40-1.

9 Hatsukami DK. Ending tobacco-caused mortality and morbidity: the case for performance standards for tobacco products. Tob Control 2013;22(Suppl 1):i36-7.

10 Backinger CL, Meissner HI, Ashley DL. The FDA "Deeming rule" and tobacco regulatory research. Tob Regul Sci 2016;2:290-3. 
11 Ashley DL, Backinger CL, van Bemmel DM, et al. Tobacco regulatory science: Research to inform regulatory action at the food and drug administration's center for tobacco products. Nicotine Tob Res 2014;16:1045-9.

12 Office of Management and Budget. Circular A-4: regulatory analysis. Washington, DC: US Office of Management and Budget, 2003.

13 Song AV, Glantz SA. Assessing tobacco regulation: moving beyond economists. Tob Control 2015;24:123-4.

14 Song AV, Brown P, Glantz SA. When health policy and empirical evidence collide: the case of cigarette package warning labels and economic consumer surplus. Am J Public Health 2014;104:e42-e51.

15 Chaloupka FJ, Gruber J, Warner KE. Accounting for "lost pleasure" in a cost-benefit analysis of government regulation: the case of the Food and Drug Administration's proposed cigarette labeling regulation. Ann Intern Med 2015;162:64-5.

16 Chaloupka FJ, Warner KE, Acemoğlu D, et al. An evaluation of the FDA's analysis of the costs and benefits of the graphic warning label regulation. Tob Control 2015;24:112-9.

17 Huang J, Chaloupka FJ, Fong GT. Cigarette graphic warning labels and smoking prevalence in Canada: a critical examination and reformulation of the FDA regulatory impact analysis. Tob Control 2014;23(Suppl 1):i7-12.

18 Cutler DM, Jessup A, Kenkel D, et al. Valuing regulations affecting addictive or habitual goods. J Benefit Cost Anal 2015;6:247-80.

19 Ashley EM, Nardinelli C, Lavaty RA. Estimating the benefits of public health policies that reduce harmful consumption. Health Econ 2015;24:617-24.

20 Zeller M. Three years later: an assessment of the implementation of the Family Smoking Prevention and Tobacco Control Act. Tob Control 2012;21:453-4.

21 Food and Drug Administration, U.S. Department of Health \& Human Services. Required warnings for cigarette packages and advertisements. Final rule. Fed Regist 2011:76:36628-777.

22 Printz C. FDA withdraws from fight over graphic warning labels on cigarette packs. Cancer 2013;119:2361

23 Chetty R. Sufficient statistics for welfare analysis: a bridge between structural and reduced-form methods. Annu Rev Econ 2009;1(1):451-487.

24 Mullainathan S, Schwartzstein J, Congdon WJ. A reduced-form approach to behaviora public finance. Annu Rev Econom 2012;4:511-40.

25 Cutler D, Jessup A, Kenkel D, et al. Valuing utility offsets to regulations affecting addictive or habitual goods. Washington, DC: Office of the Assistant Secretary for Planning and Evaluation. U.S.Department of Health and Human Services, 2015.

26 JinLKD, Lui F, Wang H. Retrospective and prospective benefit-cost analysis of U.S.antismokingpolicies. J Benefit Cost Anal 2015;6:154-86.

27 Cutler DM, Jessup Al, Kenkel DS, et al. Economic approaches to estimating benefits of regulations affecting addictive goods. Am J Prev Med 2016;50(5 Suppl 1):S20-6.

28 Food and Drug Administration, U.S. Department of Health \& Human Services. Deeming tobacco products to be subject to the federal food, drug, and cosmetic act, as amended by the family smoking prevention and tobacco control act; restrictions on the sale and distribution of tobacco products and required warning statements for tobacco products. Final rule. Fed Regist 2016:81:28973-9106.

29 Slovic P. Smoking: risk, perception \& policy Thousand Oaks, CA: Sage, 2001.

30 Slovic P. The 'value' of smoking: An editorial. Health Risk Soc 2012;14:409-14.

31 Slovic $P$, Finucane ML, Peters $E$, et al. Risk as analysis and risk as feelings: some thoughts about affect, reason, risk, and rationality. Risk Anal 2004;24:311-22.

32 Weinhold D, Chaloupka FJ. Smoking status and subjective well-being. Tob Control 2017;26:195-201.

33 Fidler JA, West R. Enjoyment of smoking and urges to smoke as predictors of attempts and success of attempts to stop smoking: a longitudinal study. Drug A/cohol Depend 2011;115:30-4.

34 Shiffman S, Terhorst L. Intermittent and daily smokers' subjective responses to smoking. Psychopharmacology 2017:2911-7.

35 Fidler JA, West R. Self-perceived smoking motives and their correlates in a general population sample. Nicotine Tob Res 2009:11:1182-8.

36 Schelling TC. Addictive drugs: the cigarette experience. Science 1992;255:430-3.

37 Read D. Which side are you on? The ethics of self-command. J Econ Psychol 2006;27:681-93.

38 Weinstein ND, Slovic P, Gibson G. Accuracy and optimism in smokers' beliefs about quitting. Nicotine Tob Res 2004;6(Suppl 3):375-80.
39 Slovic P. Do adolescent smokers know the risks? Duke Law J 1998;47:1133-41.

40 Fong GT, Hammond D, Laux FL, et al. The near-universal experience of regret among smokers in four countries: Findings from the international tobacco control policy evaluation survey. Nicotine Tob Res 2004;6(Suppl 3):341-51.

41 Borland $\mathrm{R}$, Yong $\mathrm{HH}$, Balmford J, et al. Motivational factors predict quit attempts but not maintenance of smoking cessation: findings from the international tobacco control four country project. Nicotine Tob Res 2010;12 Suppl(12 Suppl):S4-S11.

42 Lee WB, Fong GT, Zanna MP, et al. Regret and rationalization among smokers in Thailand and Malaysia: findings from the International Tobacco Control Southeast Asia Survey. Health Psychol 2009;28:457-64.

43 Sansone N, Fong GT, Lee WB, et al. Comparing the experience of regret and its predictors among smokers in four Asian countries: findings from the ITC surveys in Thailand, South Korea, Malaysia, and China. Nicotine Tob Res 2013;15:1663-72.

44 Nayak P, Pechacek TF, Slovic P, et al. Regretting ever starting to smoke: results from a 2014 national survey. Int J Environ Res Public Health 2017;14:390.

45 McIntyre D. A picture of misery: the truth about smoking, in smokers' own words: no smoking day 2002. 2002 http://www.ash.org.uk/html/cessation/nsd2002.html

46 Brown A. In U.S., smokers light up less than ever: Gallup, 2012. http://www.gallup. com/poll/157466/smokers-light-less-ever.aspx

47 The International Tobacco Control Policy. ITC United States National Report. Findings from the Wave 1 to 8 Surveys (2002- 2011). Waterloo, Ontario, Canada: University of Waterloo, 2014.

48 O'Connor RJ, Thrasher JF, Bansal-Travers M. Exploring relationships among experience of regret, delay discounting, and worries about future effects of smoking among current smokers. Subst Use Misuse 2016:51:1245-50.

49 Heatherton TF, Kozlowski LT, Frecker RC, et al. The fagerström test for nicotine dependence: a revision of the fagerström tolerance questionnaire. $\mathrm{Br} J$ Addict 1991;86:1119-27.

50 Kozlowski LT, Porter CQ, Orleans CT, et al. Predicting smoking cessation with selfreported measures of nicotine dependence: FTQ, FTND, and HSI. Drug Alcohol Depend 1994;34:211-6.

51 Muscat JE, Stellman SD, Caraballo RS, et al. Time to first cigarette after waking predicts cotinine levels. Cancer Epidemiol Biomarkers Prev 2009;18:3415-20.

52 Weaver SR, Majeed BA, Pechacek TF, et al. Use of electronic nicotine delivery systems and other tobacco products among USA adults, 2014: results from a national survey. Int J Public Health 2016;61:177-88.

53 Piper ME, Kenford S, Fiore MC, et al. Smoking cessation and quality of life: changes in life satisfaction over 3 years following a quit attempt. Ann Behav Med 2012;43:262-70.

54 Stickley A, Koyanagi A, Roberts B, et al. Smoking status, nicotine dependence and happiness in nine countries of the former Soviet Union. Tob Control 2015:24:190-7.

55 Shahab L, West R. Differences in happiness between smokers, ex-smokers and neve smokers: cross-sectional findings from a national household survey. Drug Alcohol Depend 2012;121:38-44.

56 Wang MP, Wang X, Lam TH, et al. Ex-smokers are happier than current smokers among Chinese adults in Hong Kong. Addiction 2014;109:1165-71.

57 Shahab L, West R. Nicotine \& tobacco research. Nicotine and Tobacco Research 2009;11:553.

58 Taylor G, Girling A, McNeill A, et al. Does smoking cessation result in improved menta health? A comparison of regression modelling and propensity score matching. BMJ Open 2015:5:e008774.

59 Taylor G, McNeill A, Girling A, et al. Change in mental health after smoking cessation: systematic review and meta-analysis. BMJ 2014;348:g1151.

60 Graham C. Unequal life chances and choices: how subjective well-being metrics can inform benefit-cost analysis. J Benefit Cost Anal 2016;7:121-46.

61 Robinson LA. [Ir] rationality, happiness, and benefit-cost analysis: introduction to the special issue. J Benefit Cost Anal 2016;7:1-11.

62 Cobb CLL, M.S.S. Gross, W. The prevalence and impact of self-selection bias and panel conditioning on smoker studies using established internet panels. Raleigh, North Carolina: Southern Association for Public Opinion Research, 2012

63 Caraballo RS, Giovino GA, Pechacek TF. Self-reported cigarette smoking vs. serum cotinine among U.S. adolescents. Nicotine Tob Res 2004;6:19-25. 